Sains Malaysiana 47(1)(2018): 85-89

http://dx.doi.org/10.17576/jsm-2018-4701-10

\title{
Captan Utilization by a Soil Bacterium Planomicrobium flavidum Strain EF
}

(Penggunaan Captan oleh Bakteria Tanah Strain EF Planomicrobium flavidum)

\author{
EMAn MoHAMED* \& FATMa ABd El-Motaleb Mostafa
}

\begin{abstract}
The fungicide captan, which is commonly used to control fungal diseases in many plants, causes soil infertility and cancer to human beings. Hence, this fungicide was tested for utilization as a sole carbon source by a newly soil isolate, Planomicrobium flavidum strain EF. This bacterium resists captan up to 2000 ppm and showed higher growth patterns in minimum salt medium supplemented with captan only, if compared with minimum salt medium without captan. Moreover, almost $77.5 \%$ of captan has been utilized by Planomicrobiu flavidum after only 2 h of growth under shaking conditions and only $0.8 \%$ of the fungicide was remained after $24 \mathrm{~h}$ of bacterial growth. Captan residues in both soil samples and minimal salt medium were accurately estimated using GC-ECD (gas chromatography - electron detector) and GC-MS/MS (gas chromatography - mass spectrum) technologies. According to current results, Planomicrobium flavidum strain EF is highly recommended for captan and may be other fungicides bioremediation.
\end{abstract}

Keywords: Captan; GC-ECD; GC-MS/MS; Planomicrobium flavidum

\section{ABSTRAK}

Racun kulat captan, yang biasanya digunakan untuk kawalan penyakit kulat dalam kebanyakan tumbuhan telah menyebabkan ketidaksuburan tanah dan kanser kepada manusia. Oleh yang demikian, racun kulat ini diuji untuk penggunaan sebagai sumber karbon tunggal melalui pencilan tanah baharu, strain EF Planomicrobium flavidum. Bakteria rintang captan ini sehingga 2000 ppm dan menunjukkan corak pertumbuhan yang lebih tinggi dalam medium garam minimum yang ditambah dengan captan sahaja, jika dibandingkan dengan medium garam minimum tanpa captan. Selain itu, hampir $77.5 \%$ daripada captan telah digunakan oleh Planomicrobiu flavidum hanya selepas dua jam pertumbuhan dalam keadaan goncangan dan hanya $0.8 \%$ daripada racun kulat ini kekal selepas 24 jam pertumbuhan bakteria. Sisa captan dalam kedua-dua sampel tanah dan medium garam minimum telah dianggarkan secara tepat menggunakan teknologi GC-ECD (kromatografi gas - pengesan elektron) dan GC-MS/MS (gas kromatografi - spektrum jisim). Mengikut keputusan semasa, strain EF Planomicrobium flavidum amat disyorkan sebagai captan dan mungkin sebagai bio pemulihan racun kulat lain.

Kata kunci: Captan; GC-ECD;GC-MS/MS; Planomicrobium flavidum

\section{INTRODUCTION}

In order to support human growing population, high crop production should be maintained and therefore, pesticides use will be expectedly increased. Fortunately, microorganisms are playing a vital role in degradation of such toxic compounds (Ye et al. 2004). Captan $\left(\mathrm{C}_{9} \mathrm{H}_{8} \mathrm{Cl}_{3} \mathrm{NO}_{2} \mathrm{~S}\right)$ is a broad- spectrum, non-systemic fungicide which is commonly used to control disease in vegetables, fruits and other crops (Agriculture \& Agri-Food Canada 1997). It is also used to inhibit fungal growth on many industrial products such as leather, paper, plastics, plasters and textiles (Rawan et al. 2008). Fungicides targeting non-specific binding sites can directly affect non target organisms and therefore, fungicide use may have negative impacts that are difficult to predict (Yang et al. 2011). Captan for instance, is mutagenic and carcinogenic to human beings and poisoning to some animals (Shirasu et al. 1976). It is a potent mutagen in both prokaryotes and eukaryotes (Hines et al. 2008; Kada et al. 1974; Rahden-
Staron et al. 1994; Robert 1989). Besides, it is highly toxic to fish and aquatic life (Tomin 2000; U.S. Environmental Protection Agency 2009). Moreover, captan causes soil infertility by killing soil microorganisms necessary for nitrogen fixation and phosphate and other nutrient absorption (Martinez-Toledo et al. 1998).

Captan persistence in soil differs according to environmental conditions. Its stability increases with decrease in $\mathrm{pH}$ and soil moisture content (Agriculture \& Agri-Food Canada 1997; Goring 1972). Accordingly, degradation of captan using safe and proper strategy is a necessary requirement. Few reports are available for captan degradation by freely suspended cells of soil microorganisms (More et al. 2014). However, Megadi et al. (2010) reported the use of captan by a strain of Bacillus circulans as a sole source of carbon and energy (Megadi et al. 2010). More recently, More et al. (2014) reported an enhanced degradation of captan by immobilized cells of Bacillus circulans. 
In this investigation, we studied the ability of the newly isolated soil bacterium, Planomicrobium flavidum strain EF to utilize the fungicide captan as a sole carbon and energy source during its growth. Besides, bacterial resistance to captan was also tested using Planomicrobium flavidum and other common bacteria found in the environmental sample. Captan residues were accurately estimated using GC-ECD and GC-MS/MS technologies.

\section{MATERIALS AND METHODS}

\section{SOURCE OF SAMPLE AND BACTERIAL ISOLATION}

Three different soil samples (less than $1 \mathrm{~cm}$ in depth) were collected and mixed together, in May- 2016, directly after applying captan (125 gm/100 L, Arysta Life Science, France) on an apple farm to control apple scab disease. The farm located at Ahmad Oraby Village, Nubarya, Beheera Governorate, Egypt. One gram of the soil mixture was agitated in $100 \mathrm{~mL}$ of sterile and distilled water. $0.1 \mathrm{~mL}$ of soil suspension was mixed with melted nutrient agar in Petri-dishes after performing different serial dilutions. Total bacterial count was estimated after $48 \mathrm{~h}$ incubation at $33^{\circ} \mathrm{C}$. Bacterial colonies were then purified and maintained in glycerol.

\section{CAPTAN ESTIMATION IN THE SOIL SAMPLE AND SOLUTIONS}

Soil mixture and minimal salt medium containing the pesticide were handled before captan estimation according to Attallah et al. (2012). Captan residues in the environmental sample and liquid minimum salt medium were quantified using GC-MS/MS (gas chromatography- mass spectrometry) and GC-ECD (gas chromatography- electron capture detector), respectively. For GC-MS/MS analysis, Agilent 7980 GC with 7000B Quadrupole equipped with Electron Impact (EI) ionization source was used for pesticide identification and quantitation. Separation was attained by injecting of $1 \mu \mathrm{L}$ of the sample to Agilent DB-35ms Ultra Inert GC columns (35\%-Phenyl)-methylpolysiloxane with dimensions $20 \mathrm{~m} \times 0.18 \mathrm{~mm} \times 0.18 \mu \mathrm{m}$. GC oven conditions were as follows: Initial oven temperature of $70^{\circ} \mathrm{C}$ for $2 \mathrm{~min}$, heating from 70 to $135^{\circ} \mathrm{C}$ at $50^{\circ} \mathrm{C} / \mathrm{min}$, holding for $0 \mathrm{~min}$ at $135^{\circ} \mathrm{C}$, heating from 135 to $200^{\circ} \mathrm{C}$ at $6^{\circ} \mathrm{C} / \mathrm{min}$, holding for $0 \mathrm{~min}$ at $200^{\circ} \mathrm{C}$, heating from 200 to $310^{\circ} \mathrm{C}$ at $16^{\circ} \mathrm{C} / \mathrm{min}$ and holding for $8.2 \mathrm{~min}$. The total run time is $30 \mathrm{~min}$. MS conditions were as follows, MS source: $\mathrm{EI}-70 \mathrm{eV}$, quadrupole temperature: $180^{\circ} \mathrm{C}$, transfer line temperature: $320^{\circ} \mathrm{C}$, gain: 40, acquisition mode: MRM, dwell time: $10 \mathrm{~ms}$ and solvent delay time: $5 \mathrm{~min}$. For GC-ECD, Gas Chromatograph HP 6890 equipped with two electron capture detectors was used, following the instructions mentioned in the instrument log book for operation, calibration and sequence procedures. The gas chromatograph instrument was adjusted for injector temperature of $225^{\circ} \mathrm{C}$ and detector temperature of $300^{\circ} \mathrm{C}$. Flow rate of nitrogen is $1.3 \mathrm{~mL} / \mathrm{min}$ and carrier total flow rate (carrier + makeup) is $55 \mathrm{~mL} / \mathrm{min}$. Oven program was as follows, initial temperature: $90^{\circ} \mathrm{C}$ and initial time: $2 \mathrm{~min}$.
For level 1 , flow rate is $20^{\circ} \mathrm{C} / \mathrm{min}$, temperature is $150^{\circ} \mathrm{C}$ and time is $0 \mathrm{~min}$. For level 2 , flow rate is $6^{\circ} \mathrm{C} / \mathrm{min}$, temperature is $270^{\circ} \mathrm{C}$ and time is $15 \mathrm{~min}$ (Angioni et al. 2003; Gilvydis \& Walters 1991).

\section{BACTERIAL RESISTANCE TO CAPTAN}

The pure bacterial cells were cultured in nutrient agar plates supplemented with different concentrations of captan, 50 to $2000 \mathrm{ppm}$. The plates were incubated at $33^{\circ} \mathrm{C}$ for $48 \mathrm{~h}$.

\section{CAPTAN BIODEGRADATION AND GROWTH MONITORING}

A promising bacterial colony was selected according to captan resistance test results and refreshed before subjecting to grow in the presence of captan as a sole carbon and energy source. Captan was added to $50 \mathrm{~mL}$ sterile minimum medium (MM) in a final concentration of $100 \mathrm{ppm}$. A separately sterilized yeast extract solution was added to captan MM in a final concentration of $1 \%$ for growth induction. Finally, the selected bacterium suspension was added to the mixture (1\%) and its ability to grow in such minimum medium was tested under shaking conditions $(150 \mathrm{rpm})$ at $33^{\circ} \mathrm{C}$. Bacterial growth $\left(\mathrm{OD}_{550}\right)$ and captan residues were estimated throughout time intervals till $30 \mathrm{~h}$. The MM composition was as follows in $\mathrm{g} / \mathrm{L}: \mathrm{Na}_{2} \mathrm{HPO}_{4}, 2.2 ; \mathrm{KH}_{2} \mathrm{PO}_{4}, 1.4$; $\mathrm{MgSO}_{4} .7 \mathrm{H}_{2} \mathrm{O}, 0.6 ;\left(\mathrm{NH}_{4}\right)_{2} \mathrm{SO}_{4}, 0.3 ; \mathrm{NaCl}, 0.05 ; \mathrm{CaCl}_{2}$, $0.02 ; \mathrm{FeSO}_{4} .7 \mathrm{H}_{2} \mathrm{O}, 0.01$ and $\mathrm{pH}, 7$ (Tallur et al. 2008).

Bacterial growth in absence of captan was also monitored using the same previously mentioned nutritional and environmental conditions to compare between the growth patterns in absence and presence of the fungicide.

\section{PHENOTYPING AND 16S RDNA PARTIAL SEQUENCING}

Gram stain was used to detect cell morphology of the newly isolated bacterium. DNA was extracted using GeneJet PCR Purification Kit (Thermo Fisher Scientific). Amplification of the 16S rDNA and amplicons purification were done according to Mohamed (2016). After DNA partial sequencing (GATC Biotech), sequences were compared with those in the GenBank data base using BLAST search (Altschul 1997). The sequences were finally depositedin the GenBank and accession number was obtained as will be indicated in the results. Forward and reverse primers (Macrogene incorporation, Seoul, Korea) used in PCR reactions and sequencing are illustrated in Table 1.

TABLE 1. Forward and reverse primers used in PCR reactions and sequencing

\begin{tabular}{lc}
\hline Primer direction & primer sequence \\
\hline Forward & 5 - AGA GTT TGA TCC TGG CTC AG-3 \\
Reverse & 5 - GGT TAC CTT GTT ACG ACT T-3 \\
\hline
\end{tabular}




\section{RESULTS}

The soil samples under test have been collected directly after applying captan $(1.25 \mathrm{gm} / \mathrm{L})$ on an apple farm to control apple scab disease. The mixed environmental sample contained captan residues of $70 \mathrm{mg} / \mathrm{kg}$ soil (average reading of 3 measurements). The same sample was analyzed for total bacterial count detection. Around $700 \mathrm{cfu}$ were counted in nutrient agar Petri-dishes after $48 \mathrm{~h}$ of incubation at $33^{\circ} \mathrm{C}$ and 8 different morphological types (data not shown) were detected.

The 8 different pure bacterial cultures were tested for their sensitivity to captan, 50-2000 ppm (Table 2). The most resistant isolate was C3 which with stands $2000 \mathrm{ppm}$ of captan followed by $\mathrm{C} 2$ that showed weak growth at 500 ppm of the fungicide. On the other hand, C7 was the most sensitive isolate followed by $\mathrm{C} 6$ and $\mathrm{C} 8$.

Due to its high captan resistance (2000 ppm), C3 was chosen for further investigations including $16 \mathrm{~S}$ rDNA partial sequencing. BLAST search indicated that C3 is Planomicrobium flavidum and its accession number in the GenBank is LC195269. This short rod-shaped, Gram- positive bacterium was allowed to grow in two different nutritional conditions. A minimum salt medium supplemented with only $1 \%$ yeast extract (growth inducer) and a minimum medium with $1 \%$ yeast extract and 100 ppm captan, a sole carbon and energy source (Figure 1).

TABLE 2. Sensitivity test of the soil bacterial isolates to different captan concentrations

\begin{tabular}{|c|c|c|c|c|c|c|c|c|}
\hline \multirow{2}{*}{$\begin{array}{l}\text { Captan concentration } \\
\text { (ppm) }\end{array}$} & \multicolumn{8}{|c|}{ Bacterial code } \\
\hline & $\mathrm{C} 1$ & $\mathrm{C} 2$ & C3 & C4 & C5 & C6 & C7 & $\mathrm{C} 8$ \\
\hline 50 & $\mathrm{r}$ & $\mathrm{r}$ & $\mathrm{r}$ & $\mathrm{r}$ & $\mathrm{r}$ & $\mathrm{r}$ & $\mathrm{s}$ & $\mathrm{r}$ \\
\hline 75 & $\mathrm{r}$ & $\mathrm{r}$ & $\mathrm{r}$ & $\mathrm{r}$ & $\mathrm{s}$ & $\mathrm{r}$ & s & $\mathrm{r}$ \\
\hline 100 & $\mathrm{w}$ & $\mathrm{r}$ & $\mathrm{r}$ & $\mathrm{r}$ & $\mathrm{s}$ & s & $\mathrm{s}$ & $\mathrm{s}$ \\
\hline 150 & $\mathrm{~s}$ & $\mathrm{r}$ & $\mathrm{r}$ & $\mathrm{r}$ & $\mathrm{s}$ & s & s & $\mathrm{s}$ \\
\hline 200 & $\mathrm{~s}$ & $\mathrm{r}$ & $\mathrm{r}$ & $\mathrm{s}$ & $\mathrm{s}$ & $\mathrm{s}$ & $\mathrm{s}$ & $\mathrm{s}$ \\
\hline 500 & $\mathrm{~s}$ & $\mathrm{w}$ & $\mathrm{r}$ & $\mathrm{s}$ & $\mathrm{s}$ & s & $\mathrm{s}$ & $\mathrm{s}$ \\
\hline 1000 & $\mathrm{~s}$ & $\mathrm{~s}$ & $\mathrm{r}$ & $\mathrm{s}$ & $\mathrm{s}$ & s & s & s \\
\hline 2000 & $\mathrm{~s}$ & $\mathrm{~s}$ & $\mathrm{r}$ & $\mathrm{s}$ & $\mathrm{s}$ & s & s & s \\
\hline
\end{tabular}

$\mathrm{r}=$ resistant; $\mathrm{s}=$ sensitive; and $\mathrm{w}=$ weak growth

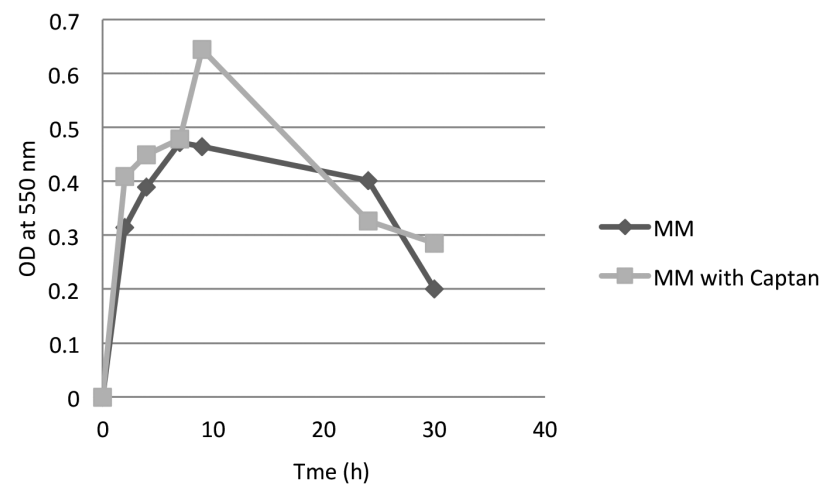

FIGURE 1. Growth curve of Planomicrobium flavidum in minimum medium (MM) and MM supplemented with 100 ppm of captan

TABLE 3. Captan content estimation ( $\mathrm{ppm}$ ) with growing Planomicrobium flavidum cells at different time intervals

\begin{tabular}{ccc}
\hline Time $(\mathrm{h})$ & Cell growth $\left(\mathrm{OD}_{550}\right)$ & Captan content $(\mathrm{ppm})$ \\
\hline 0 & 0.05 & $100 \pm 0.24$ \\
2 & 0.409 & $22.46 \pm 0.11$ \\
4 & 0.449 & $21.99 \pm 0.13$ \\
7 & 0.479 & $14.68 \pm 0.12$ \\
9 & 0.645 & $12.18 \pm 0.13$ \\
24 & 0.327 & $0.8 \pm 0.08$ \\
30 & 0.285 & $0.52 \pm 0.07$ \\
\hline
\end{tabular}


In the presence of captan, cells growth was enhanced to reach an optical density of 0.645 at $550 \mathrm{~nm}$ after $9 \mathrm{~h}$ of shaking. On the contrary, cells optical density reached only 0.464 in the absence of captan after $9 \mathrm{~h}$. This indicates the utilization of the fungicide by Planomicrobium flavidum cells as a carbon source.

To quantify the amount of captan that was utilized/ degraded by Planomicrobium flavidum, the fungicide residues were measured at different time intervals with the growing cells (Table 3 ). Surprisingly, only $22.46 \%$ of captan was detected in the liquid medium after only $2 \mathrm{~h}$ of growth under shaking conditions. The strain continued to utilize captan over time and only $0.8 \%$ and $0.52 \%$ of the fungicide were remained after 24 and $30 \mathrm{~h}$ of shaking, respectively.

\section{DISCUSSION}

Captan is a multisite activity fungicide that controls a broad spectrum of plant disease. Unfortunately, it has side effects on other microorganisms due to its multiple biochemical sites impacts (Milenkovski et al. 2010). It inhibits growth of denitrifying bacteria may be due to its nonspecific effects on biochemical compounds that contain thiol in target cells (Kostov \& Van Cleemput 2001). Interestingly, our new soil isolate, Planomicrobium flavidum EF, showed very high captan resistance, up to $2000 \mathrm{ppm}$, although the negative impact of captan on microbial flora including bacteria (Kostov \& Van Cleemput 2001). This high resistance indicates the neglected effect of captan on Planomicrobium flavidum growth.

Captan residues may remain in soil from one day to several months according to soil type, temperature and moisture content (Li \& Nelson 1985). Its persistence leads to destruction of soil microbial community (MartinezToledo et al. 1998). Accordingly, a safe, cost-effective and promising method for its removal is required, especially from aqueous solutions because it may leak to water bodies such as groundwater due to its mobility. In this study, Planomicrobium flavidum EF showed effective utilization of captan in short time, only $22.46 \%$ was remained after $2 \mathrm{~h}$ of growth. Moreover, only $0.8 \%$ of the fungicide was remained after $24 \mathrm{~h}$ of growth. In the minimum salt medium enriched with $1 \%$ yeast extract, Planomicrobium flavidum reached the log phase $\left(\mathrm{OD}_{550}=\right.$ 0.472 ) in $7 \mathrm{~h}$. On the other hand, Planomicrobium flavidum growth in captan minimum medium reached the log phase in $9 \mathrm{~h}\left(\mathrm{OD}_{550}=0.645\right)$ utilizing around $88 \%$ of captan in the medium. This emphasizes the ability of this bacterium to utilize captan as a soul carbon source for its growth. Megadi et al. (2010) have isolated a bacterial strain belonging to Bacilluscirculans that degrades captan to be used as a soul carbon source for its growth. They have also investigated in another study the degradation of captan into cis-1,2,3,6-tetrahydrophthalimide, a compound with no fungicidal activity. This later compound was further degraded to o-phthalic acid. This means a complete mineralization of captan by Bacilluscirculans (Megadi et al. 2010). Besides, Buyanovsky et al. (1988) have also investigated captan degradation by soil microbes under laboratory conditions. They declared the transformation of captan to tetrahydrophthalimide. In captan- treated soils, total count of fungi, bacteria and actinomycetes decreased at relatively high fungicide concentration (Banerjee \& Banerjee 1987) and few articles have been published for captan biodegradation (More et al. 2014). Although Planomicrobium flavidum was not reported for captan degradation before, our results showed a dramatic decrease in captan levels in a minimum salt medium contains only one carbon source, captan, when Planomicrobium flavidum was used. This indicates the degradation of the fungicide by Planomicrobium flavidum. Accordingly, this promising bacterium that is commonly found in sediment, mud, marine and fermented sea foods (Dai et al. 2005; Zhang et al. 2009) may be recommended for removal of not only captan, but also other toxic fungicides from the agricultural environment. Moreover, Das and Tiwary (2013) isolated a novel strain of Planomicrobium chinense from diesel contaminated soil of tropical environment. This bacterium can degrade high concentration of diesel oil (up to $2.5 \%$ $(\mathrm{v} / \mathrm{v}))$. This means a need for more investigations in the bioremediation field using Planomicrobium spp.

\section{CONCLUSION}

Planomicrobium flavidum strain EF is highly efficient in captan utilization in a short time. This bacterium should be used in further study to optimize its captan degradation ability and to seek for the degradation products. However, this newly isolated bacterium which did not reported before for captan remediation, could be potentially used in bioremediation of soils and water contaminated with toxic fungicides that have negative impact on soil microflora, especially those involved in vital environmental roles in agricultural soils and water bodies. The pesticide residues were precisely estimated and accurate captan levels were successfully detected in soil and aqueous samples.

\section{ACKNOWLEDGEMENTS}

The authors would like to express grateful thanks to Prof. Dr. Ashraf El-Mersafy and Dr. Emad Attallah, Central Laboratory of Residue Analysis of Pesticides and Heavy Metals in Foods, Agricultural Research Center, Ministry of Agriculture and Land Reclamation, Giza, Egypt, for their tremendous assistance in samples analyses using GC devices. Many thanks are to be extended to Prof. Dr. Azza G. Farag and Sahar Yousef (Department of Virus and Phytoplasma Research, Institute of Plant Pathology Research, Agriculture Research Centre, Egypt) for their great help in providing the laboratory facilities and technical support. 


\section{REFERENCES}

Agriculture and Agri-Food Canada. 1997. Regulatory Information on Pesticide Products (RIPP) Database (CCINFODISK). Produced by Agriculture and Agri-Food Canada and distributed by the Canadian Centre for Occupational Health and Safety. CD-ROM.

Altschul, S.F., Madden, T.L., Scaffer, A.A., Zhang, J., Zhang, Z., Miller, W. \& Lipman, D.J. 1997. Gapped BLAST and PSI- BLAST: A new generation of protein database search programs. Nucleic Acids Research 25(17): 3389-3402.

Angioni, A., Garau, V.L., Del Real, A.A., Melis, M., Minelli., E.V., Tuberoso, C. \& Cabras, P. 2003. Determination and degradation of captan during the wine-making. Journalof Agricultural Food Chemistry 51: 6761-6766.

Attallah, E.R., Amer, M.E., Gomaa, A.M. \& Elgohary, A.A. 2012. QuEChERS analytical method for determination of 93 pesticide residues in apples and potatoes using LC-MS/ MS. Journal of Applied Science Research 8(12): 5690-5697.

Banerjee, A. \& Banerjee, A.K. 1987. Influence of captan on some microorganisms and microbial procecessese related to the nitrogen cycle. Plant Soil 102: 239-245.

Buyanovsky, G.A., Pieczonka, G.J., Wagner, G.H. \& Fairchild, M.L. 1988. Degradation of captan under laboratory conditions. Bulletin of Environmental Contamination and Toxicology 40: 689-695.

Dai, X., Wang, Y.N., Wang, B.J., Liu, S.J. \& Zhou, Y.G. 2005. Planomicrobium chinense sp. nov., isolated from coastal sediment, and transfer of Planococcus psychrophilus and Planococcus alkanoclasticus to Planomicrobium as Planomicrobium psychrophilum comb. nov. and Planomicrobium alkanoclasticum comb. nov. International Journal Systematic and Evolutionary Microbiology 55: 699-702.

Das, R. \& Tiwary, B.N. 2013. Isolation of a novel strain of Planomicrobium chinense from diesel contaminated soil of tropical environment. Journal of Basic Microbiology 53(9): 723-732.

Gilvydis, D.M. \& Walters, S.M. 1991. Gas chromatographic determination of captan, folpet and captafol residues in tomatoes, cucumbers and appless using a wide-bore capillary column: Interlaboratory study. Journal of Association Official Analytical Chemistry 74(5): 830-835.

Goring, C.A.I. 1972. Fumigants, fungicides and nematicides. In Organic Chemicals in the Soil Environment, Vol. 2, edited by Goring, C.A.I. \& Hamaker, J.W. New York: Marcel Dekker Incorporation.

Hines, C.J., Deddens, J.A., Jaycox, L.B., Andrews, R.N., Striley, C.A.F. \& Alavanja, M.C.R. 2008. Captan exposure and evaluation of a pesticide exposure algorithm among orchard pesticide applicators in the agricultural health study. Annuals in Occupying Huygens 52(3): 267-278.

Kada, T., Moriya, M. \& Shirasu, Y. 1974. Screening of pesticides for DNA interactions by rec-assay and mutagenesis testing and frameshift mutagens detected. Mutation Research 26: 243-248.

Kostov, O. \& Van Cleemput, O. 2001. Microbial activity of $\mathrm{Cu}$ contaminated soils and effect of lime and compost on soil resiliency. Compost Science Utilization 9(4): 336-351.

Li, C.Y. \& Nelson, E.E. 1985. Persistence of benomyl and captan and their effects on microbial activity in field soils. Bulleten of Environmental Contamination and Toxicology 34: 150-157.

Martinez-Toledo, M.V., Salmeron, B., Rodelas, C. \& Pozo, J.G.L. 1998. Effects of fungicide captan on some functional groups of soil microflora. Appllied Soil Ecology 7: 245-255.
Megadi, V.B., Tallur, P.N., Mulla, S.I. \& Harichandra, Z.N. 2010. Biodegradation of pendimethalin by Bacillus circulans. Indian Journal of Biotechnolgy 9: 173-177.

Milenkovski, S., Baath, E., Lindgren, P.E. \& Berglund, O. 2010. Toxicity of fungicides to natural bacterial communities in wetland water and sediment measured using leucine incorporation and potential denitrification. Ecotoxicology19(2): 285-294.

Mohamed, E.A.H. 2016. Biophysical removal of some toxic heavy metals by Aeromonas strains. Journal of Pure and Applied Microbiology 10(1): 311-316.

More, V., Tallup, P., More, S.S., Niyozima, F.N. \& Ninnekar, H. 2014. Enhanced degradation of captan by immobilized cells of Bacillus circulans. Journal of Microbiology and Biotechnology of Food Science 4(2): 108-111.

Rahden-Staron, I., Szumilo, M. \& Ziemkiewicz, P. 1994. The effect of captan and captafol on different bacterial strains and on c-mitosis in V79 Chinese hamster fibroblasts. Acta Biochimstry Polleten 41: 45-55.

Rawn, D.F.K., Quade, S.C., Sun, W.F., Fouguet, A., Belanger, A. \& Smith, M. 2008. Captan residue reduction in apples as a result of rinsing and peeling. Food Chemistry 109: 790-796.

Roberts, L. 1989. Pesticides and kids. Science 243: 1280.

Shirasu, Y., Moriya, M., Kato, K., Furuhashi,A. \& Kada, T. 1976. Mutagenicity screening of pesticides in the microbial system. Mutation Research 40: 19-30.

Tallur, P.N., Megadi, V.B. \& Ninnekar, H.Z. 2008. Biodegradation of cypermethrin by Micrococcus sp. strain CPN1. Biodegradation 19: 77-82.

Tomin,C.D.S. 2000.The Pesticide Manual: A World Compendium. 12th ed. British Crop Protection Council, Farnham, U.K. pp. 132-133.

U.S. Environmental Protection Agency. 2009. Registration Eligibility Decision (RED): Captan, EPA: Washington DC, http:// www.epa.gov/oppsrrdl/REDs/0120red.

Yang, C., Hamel, C., Vujanovic, V. \& Yantai, G. 2011. Fungicide: Modes of action and possible impact on nontarget microorganisms. ISRN Ecology. Article ID. 130289.

Ye, J., Singh, A. \& Ward, O.P. 2004. Biodegradation of nitroaromatics compounds and other nitrogen-containing xenobiotics. World Journal of Microbiology and Biotechnology 20: 117-135.

Zhang, D.C., Liu, H.C., Xin, Y.H., Yu, Y., Zhou, P.J. \& Zhou, Y.G 2009. Planomicrobium glaciei sp. nov., a psychrotolerant bacterium isolated from a glacier. International Journal of Systematic and Evolutionary Microbiology 59: 1387-1390.

Eman Mohamed*

Botany and Microbiology Department

Faculty of Science, Damanhour University, Damanhour Egypt

Fatma Ahmad Mostafa

Plant Pathology Research Institute

Agriculture Research Centre (ARC), Giza

Egypt

*Corresponding author; email: emanahm@hotmail.com

Received: 31 January 2017

Accepted: 6 July 2017 